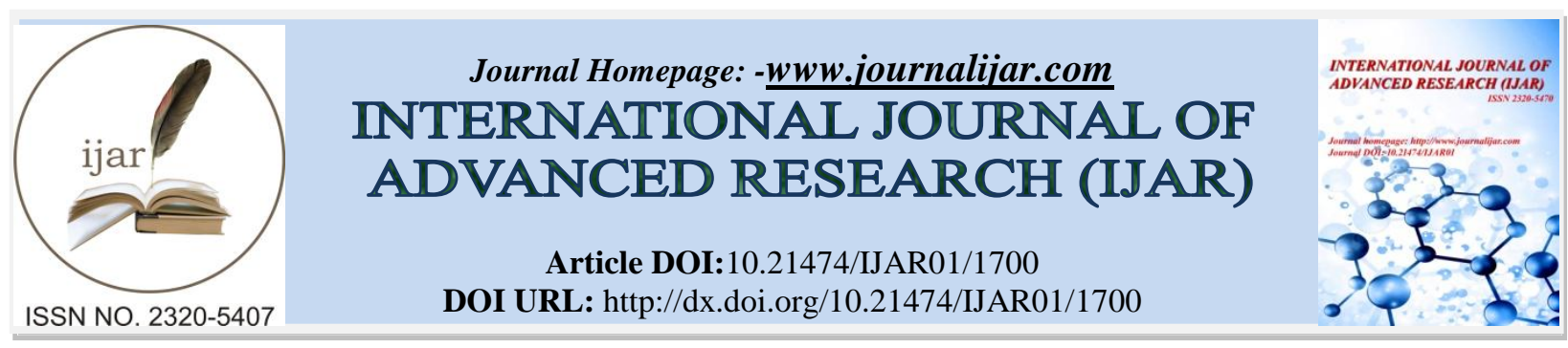

RESEARCH ARTICLE

\title{
A NOVEL AND EFFECTIVE CLOSTRIDIUM BIFERMENTANS CPSS2 AGAINST SELECTED FISH PATHOGENIC BACTERIA.
}

\section{Arunjyoti Baruah ${ }^{1}$, Rakesh Das ${ }^{2 *}$, Saurav Kumar ${ }^{3}$, Pragyan Roy $^{2}$, Adhikari Sahu ${ }^{2}$, Soumya Prasad Panda ${ }^{2}$,} S. S. Mishra ${ }^{2}$ and B. K. Das ${ }^{2}$.

1. Division of Fisheries Science, ICAR-Central Island Agricultural Research Institute, Port Blair, A\&N Island.

2. Fish Health Management Division, ICAR-Central Institute of Freshwater Aquaculture, Bhubaneswar, Odisha.

3. Aquatic Environment and Health Management Division, ICAR-Central Institute of Fisheries Education, Versova, Mumbai.

\section{Manuscript Info}

Manuscript History

Received: 12 August 2016

Final Accepted: 22 September 2016

Published: September 2016

Key words:-

Isolation, Clostridium bifermentans,

Pathogenic bacteria, Antagonistic, In-

vitro, Bio-control.

\section{Abstract}

Several bacterial species induces a variety of fish diseases, resulting in a severe reduction of aquaculture output. However, the current fish disease control is mainly dependent on the environmental friendly chemical formulations. Thus, the present work aimed to isolate an effective antagonistic microorganism against common fish pathogenic bacteria. A total six isolates were isolated, among them one isolate showed antibacterial efficacy in in-vitro conditions. The isolated bacterium was identified as Clostridium bifermentans (GenBank accession No. KT367517). The inhibitory activity of $C$. bifermentans CPSS2 was evaluated at 25, 50 and $100 \mu \mathrm{l}\left(\mathrm{OD}_{600}=1.0 ; 1 \times 10^{8} \mathrm{cfu} / \mathrm{ml}\right)$ against pathogenic strain of FlavobacteriumcolumnareATCC 49513, Staphylococcus aureus JQ429749, AeromonashydrophilaJQ687063 and EdwardisellatardaJX280148 $\left(2.6 \pm 0.5 \times 10^{9} \mathrm{cfu} / \mathrm{ml}\right)$ in agar well diffusion method and was validated by a broth co-culture assay with their kinetics plots. Extracted intracellular protein of $C$. bifermentans CPSS2 exhibited significantly $(\mathrm{p}<0.05)$ high antagonistic effect against $S$. aureus JQ429749 followed by $F$. columnareATCC 49513and A. hydrophila JQ687063 and was least effective against $E$. tardaJX280148.The results of co-culture plate counts infer increasing count of C. bifermentans CPSS2 colonies positively antagonistic against the fish pathogenic bacteria. The result of phylogenetic study revealed that the isolated strain of $C$. bifermentans is closely related to C. bifermentans E079. The screening of inhibitory compounds from bacterium have clearly demonstrated that whole live bacteria and intracellular protein of $C$. bifermentans CPSS2 would be one of promising bio-control agent against common fish pathogen in freshwater aquaculture sector.

Copy Right, IJAR, 2016,. All rights reserved.

Corresponding Author:-Rakesh Das, ICAR-Central Institute of Freshwater Aquaculture, Fish Health Management Division, Kausalyaganga, Odisha 


\section{Introduction:-}

Aquaculture is one of the fastest growing food producing sector, and has grown tremendously during the last decades and contributed significantly in agricultural and total Gross Domestic Product (GDP) of India (Subasinghe, Soto \&Jia2009; MPEDA 2014). The progress of fish farming is assisted with relevant management practices; however the concerns like deteriorating the environmental qualities and emergence of new infectious diseases are not to be denied. Indeed, in all animal industries, intensification generates high involvement of component of triad (host, pathogen and environment) and unbalances the system that initiates disease processes and fish mortality (Seenivasan, SaravanaBhavan, Radhakrishnan\&Muralisankar 2012). Mostly, bacterial diseases are responsible for severe economic losses and huge mortalities in aquaculture industries worldwide (Bondad-Reantaso, Rohana, J, Kazuo, Supranee, Robert, Zilong\& Mohamed 2005; Desriac, Defer, Bourgougnon, Brillet, Le \& Fleury 2010). However, numerous chemotherapeutants and preventive measures are effectively used and well documented to control the bacterial pathogens in aquaculture. In addition to it, continuous use of antibiotics to control pathogenic microorganisms result in alterations in the normal micro biota of the aquaculture systems, increasing resistance to common antimicrobials, residual effect, environmental issues and many more including consumer safety (Ding \& He 2010; Resende, Silva, Fontes, Souza-Filho, Rocha, Coelho \&Diniz 2011). Therefore, alternative strategies to be developed to prevent opportunistic infections in aquaculture. The development of biocontrol agents appears to be one of the most promising ways to reach this goal (Merrifield, Arkadios, Andrew, Simon, Remi, Baker, Mathieu \&Einar 2010). Bio-control agents are live cell preparations having beneficial effects like improving its feed conversion ratio, enzymatic contribution to digestion, inhibition of pathogenic microorganism's growth promoting factors and increase immune responses of the host (Verschuere, Rambaut, Sorgeloos\&Vestracte 2000). Currently, prevention of fish diseases by the application of live pathogen-antagonistic bacteria has received widespread importance and application of probiotics are gaining much popularity (Vine, Leukes\& Kaiser 2004;Dhanasekaran, Subhasish, Thajuddin, Panneerselvam 2008;Authira, Kirithik, Venkatesan, Ganesan\&Muthuchelian 2011;LaraFlores 2011; Tabak, Maghnia\&Bensoltane 2012). The common probiotics that are used for aquaculture practices include Lactobacillus, Lactococcus, Leuconostoc, Enterococcus, Carnobacterium, Shewanell, Bacillus, Aeromonas, Vibrio, Enterobacter, Pseudomonas, Clostridium, and Saccharomyces species.

Aeromonashydrophila, Flavobacteriumcolumnare, Edwardisellatardaand Staphylococcus aureus are the commonest fish pathogenic bacteria in the mainly in the tropical freshwater aquaculture system. Previously work has been carried out on antagonistic activity of cellular components of Pseudomonas species against A. hydrophila and its effect on Cirrhinusmrigala(Das, Samal, Samantaray, Sethi, Pattanaik\& Mishra 2006). Similarly heat treated Bacillus subtilis was exhibited antagonistic activity against bacterial pathogens which resulted in significantly decreasing the fish pathogenic bacteria under in vitro condition (Das, Neha, Roy, Muduli, Swain, Mishra \&Jayasankar 2014). Beneficial bacteria, such as Lactobacillus and Bifidobacterium bifidum, have the ability to kill other bacteria by secreting small quantities of antibiotic-like substances, including lactic-acid, acetic acid, benzoic-acid, hydrogen peroxide acidolin, lactocidin and acidophilin (Vidya\&lyer 2010). However, the information on bio-control agents those are isolated from natural resources like water or soil is scanty. Moreover, the selection criteria for effective biocontrol agent mainly depend on its visible antagonistic efficacy under in vitro condition. Keeping this backdrop information, the present study was conducted to isolate and identify biocontrol agent (bacteria) on biochemical and molecular basis and to investigate the in vitro antibacterial efficacy against selected fish pathogenic bacteria.

\section{Materials and Methods:- Collection of samples:-}

Pond mud samples were collected from semi intensive aquaculture ponds of ICAR-CIFA, Bhubaneswar and kept in sterile zip locked polythene bags (Hi Media, India). Soil samples (1 gram each) were dissolved in $10 \mathrm{ml}$ of sterile distilled water and filtered through Whatman Filter paper No. 40 in vertical laminar flow clean air work station $\left(\mathrm{Klenzflo}^{\mathrm{TM}}\right)$ at room temperature. Filtered sample was serially diluted in normal saline $(0.85 \% \mathrm{NaCl})$ for $24 \mathrm{hours}$ at $28^{\circ} \mathrm{C}$. Individual colonies based on the morphology were picked, purified and stored at $4^{0} \mathrm{C}$ for further identification (Joseph, Sasidharan, Nair\& Bhat 2013). The pathogenic bacterial strains viz., FlavobacteriumcolumnareATCC 49513, Staphylococcus aureus JQ429749, AeromonashydrophilaJQ687063 and EdwardisellatardaJX280148 maintained in soft agar (1\% Agar) media were used in the study for the antagonistic study against identified $C$. bifermentans CPSS2. Further enriched bacterial populations were inoculated in the nutrient agar at $24^{0} \mathrm{C}$ for $24 \mathrm{~h}$.. 


\section{Molecular identification of bacterial isolates:-}

Genomic DNA of purified colonies (small, spherical and elevated blackcolour) was extracted (Leja, Myszka, Olejnik-Schmidt, Juzwa\&Czaczyk 2014) with partial modification of (Joseph, Sasidharan, Nair \& Bhat 2013). In brief, bacterial cells from a 24 hours old broth culture were subjected to centrifugation ( $8000 \mathrm{x} g$ for $10 \mathrm{~min}$ ) and pellets were harvested, re-suspended in TE (Tris-EDTA) buffer (10 mMTris/HCl, 1mM EDTA, pH 8.0), treated with $10 \%(\mathrm{w} / \mathrm{v})$ SDS and proteinase $\mathrm{K}(20 \mathrm{mg} / \mathrm{ml})\left(\right.$ Sigma) and incubated at $37^{\circ} \mathrm{C}$ for 1 hour 30 minutes. After incubation, $10 \%$ cetyltrimethyl ammonium bromide (CTAB) in $0.5 \mathrm{M} \mathrm{NaCl}$ was added and the mixture incubated at $65^{\circ} \mathrm{C}$ for $20 \mathrm{~min}$. The DNA pellet was washed with chilled ethanol and suspended in TE for downstream processing. The concentration was estimated spectrophotometrically at $600 \mathrm{~nm}$ and appropriate dilutions (50-100ng) were used as template for PCR reactions.

\section{S rRNA gene sequencing of the isolates:-}

The 16S rRNA gene was amplified using the Forward primer (5'-AAGAGTTTGATCCTGGCTCAG-3') and Reverse primer (5'-GGTTACCTTACGACTT-3'). Each PCR reaction containing $0.2 \mu \mathrm{M}$ dNTP (BangloreGenei), 10 picomole each primers, $1.25 \mathrm{mM}$ of $\mathrm{MgCl}_{2}, 1 \mathrm{X}$ assay buffer and $0.5 \mathrm{U}$ of Taq DNA polymerase (BangloreGenei) with $20 \mathrm{ng}$ of DNA template. The procedure of PCR amplification was as follows: $95^{\circ} \mathrm{C}$ for 5 min initial denaturation followed by 35 cycles of $95^{\circ} \mathrm{C}$ for $1 \mathrm{~min}, 55^{\circ} \mathrm{C}$ for $1 \mathrm{~min}, 72^{\circ} \mathrm{C}$ for $1 \mathrm{~min}$. and a final extension step at $72^{\circ} \mathrm{C}$ for $7 \mathrm{~min}$. that carried out in an automatic thermal cycler (Applied Biosystem). PCR products $(\sim 1,500 \mathrm{bp}$ fragments) were electrophoresed through $1.2 \%$ agarose gel and visualized by UV transillumination after staining with ethidium bromide. Products after PCR amplification were purified by gel extraction kit (Sigma Aldrich). Positive PCR products were sent to Sci Genome Laboratory Pvt. Ltd for DNA (Sanger Di-doxy) sequencing. The 16S rRNA gene sequence of bacterial isolate was submitted to the National Centre for Biotechnology Information (NCBI, http://blast.ncbi.nlm.nih.gov ) for BLAST search. Sequences were imported into Molecular Evolutionary Genetics Analysis (MEGA) version 5.0 software (Tamura, Peterson, Stecher, Nei\& Kumar 2011), with which a sequence alignment and phylogenetic tree were created on the basis of the neighbour-joining method.

\section{Screening for antagonistic effect in agar diffusion assay:-}

The bacterial inhibitory activity of selected isolate designated as Clostridium bifermentans CPSS2 was evaluated against FlavobacteriumcolumnareATCC 49513, Staphylococcus aureus JQ429749, AeromonashydrophilaJQ687063 and EdwardisellatardaJX280148 with the agar well diffusion method (Harris, Daeschel, Klaenhammer 1989). The fish pathogenic bacteria at $2.6 \pm 0.5 \times 10^{9} \mathrm{cfu} / \mathrm{ml}(100 \mu \mathrm{l})$ after adjusting to the colonies as per the OD value was seeded over the Tryptone Soya Agar (HiMedia Laboratories, India) plates (Gram \&Melchiosen 1996). Each well filled with 25,50 and $100 \mu \mathrm{l}$ of $C$. bifermentansCPSS2. The plates were incubated at $28{ }^{\circ} \mathrm{C}$ for $24 \mathrm{~h}$. The antibacterial activity of $C$. bifermentans CPSS2 was defined as the diameter of the clear inhibitory zone (mm) formed around the $4 \mathrm{~mm}$ diameter well. One solvent blank (broth solution) was used per plate, and each test was run in duplicate (Spanggaard, Huber, Nielsen, Sick, Pipper, Martinussen, Slierendrecht\& Gram 2001).

\section{Screening for antagonistic effect in broth co-culture assay:-}

The antagonistic effects of $C$. bifermentans CPSS2 was observed in the diffusion agar assay and were validated by a broth co-culture assay with their kinetics. $C$. bifermentans $\mathrm{CPSS} 2\left(\mathrm{OD}_{600}=1.0,1.6 \times 10^{10}\right.$ cells $)$ were added to $1 \mathrm{~mL}$ of nutrient media (HiMedia Laboratories, India) in competition with different fish pathogenic bacteria $\left(\mathrm{OD}_{600}=1.0 \times 10^{10}\right.$ cells $)$ and designated as:

$\mathrm{T} 1=1.0 \mathrm{ml}$ of fish pathogenic bacteria with $0.5 \mathrm{ml}$ of $C$. bifermentansCPSS2

$\mathrm{T} 2=1.0 \mathrm{ml}$ of fish pathogenic bacteria with $1.0 \mathrm{ml}$ of $C$. bifermentansCPSS2

$\mathrm{T} 3=1.0 \mathrm{ml}$ of fish pathogenic bacteria with $1.5 \mathrm{ml}$ of $C$. bifermentansCPSS2 and

$\mathrm{T} 4=1.0 \mathrm{ml}$ of fish pathogenic bacteria with $2.0 \mathrm{ml}$ of $C$. bifermentans $\mathrm{CPSS} 2$

Co culture was performed with the fixed volume of pathogenic bacteria corresponding to the fixed colonies with variable quantity of $C$. bifermentansCPSS2 as described in the treatments (T1-T4). These co-cultures were made in triplicates and incubated for $96 \mathrm{~h}$ at $28^{\circ} \mathrm{C}$. The incubated co-cultures were streak on nutrient agar for colony count and corresponding OD at $600 \mathrm{~nm}$ were measured on $0,24,48,72$ and $96 \mathrm{~h}$. The incubated cultures were diluted and growth of both $C$. bifermentans CPSS2 and pathogens was observed by spreading the co-culture on nutrient agar plate along with morphological identification and counting. Further a kinetic graph was plotted.

Extraction of extracellular and intracellular protein and in vitro efficacy of antibacterial activity 
Extracellular and intracellular protein of the bacterial cell was obtained as followed by standard method (Austin \& C 1981). In brief, An $18 \mathrm{~h}$ post incubated log phage culture of $C$. bifermentansCPSS2 bacteria was centrifuged at the rate of $8000 \mathrm{x} g$ for 45 minutes, the supernatant was collected and filtered through $0.45 \mu \mathrm{m}$ membrane . Further, the bacterial cell pellet was washed twice with $2 \mathrm{ml}$ of PBS pH 7.4, and re-suspended in Phosphate Buffered Saline (PBS) in $1.5 \mathrm{ml}$. The different treatment viz., heat killed $\left(60^{\circ} \mathrm{C}\right.$ for $\left.10 \mathrm{~min}\right)$, sonicated $(50 \mathrm{~Hz}$ for $15 \mathrm{~min})$ of $C$. bifermentans CPSS2 bacteria and intracellular protein of $C$. bifermentansCPSS2 were respectively tested for antagonistic efficacy and performed well diffusion assay for evaluation of antibacterial activity.

\section{Results:-}

Screening of micro-biota from aquaculture pond:-

The six types of bacterial colonies were grown from the soil sample where Clostridium sp. and Bacillus sp. were found to be predominated. The isolates identified from pond soil as biocontrol agent against fish pathogenic bacteria, formed small, spherical and elevated black color colonies on TSA plates and were Gram positive motile rods. Biochemical tests revealed that they were negative for urease, inuline fermentation, trehalose and rhamnose fermentation and positive for mannose fermentation, indole, mannitol assimilation, citrate utilisation and glucose fermentation (Table 1). The amplified 16S rRNA gene from the isolate was sequenced and BLAST analysed and the results revealed 98\% homology with $C$. bifermentans. The new isolate submitted as Accession No. KT367517. The phylogenetic analysis of isolated $C$. bifermentans CPSS2 was revealed to close with $C$. bifermentans E079 strain (Figure 5).

Screening for antagonistic effect of selected strain in agar diffusion assay:-

The identified $C$. bifermentansCPSS2 were screened for antagonistic affects against four fish pathogenic bacteria $F$. columnareATCC 49513, S. aureus JQ429749, A. hydrophilaJQ687063 and E. tardaJX280148 by an agar diffusion assay. In all assays, zone of inhibition (in $\mathrm{mm}$ ) were observed against selected fish pathogenic bacteria (Figure 1). ClostridiumbifermentansCPSS2 was showed significantly $(\mathrm{p}<0.05)$ high zone of inhibition against $S$. aureus JQ429749 $(15.33 \pm 0.35 \mathrm{~mm})$ followed by $F$. columanare ATCC $49513(14.00 \pm 0.30 \mathrm{~mm})$ and andA.hydrophilaJQ687063 $(12.33 \pm 0.35 \mathrm{~mm})$ however, significantly less zone of inhibition was observed against Gram negative E. tardaJX280148. In the present study, results revealed that with the increase of concentration of $C$. bifermentansCPSS2 reflected to higher antagonistic activity against said fish pathogenic bacteria i.e. 100 $\mu 1$ inoculum has more antagonistic activity compare to 25 and $50 \mu 1$ of $C$. bifermentansCPSS2 (Figure 2).

\section{Validation of antagonistic effect in broth co-culture assay:-}

In order to validate the presence of a competitive effect, the $C$. bifermentans CPSS2 exhibiting antagonistic effects were tested in broth co-culture assays with the fish bacterial pathogens. In most of cases, counts of $C$. fermentans CPSS2 were found higher when compared to fish pathogenic bacteria. The specific co-cultures of Clostridium and fish pathogenic bacteria were found significantly competitive against the gram positive $S$. aureus JQ429749 at 48 hours of incubation, whereas less effective against gram negative E. tarda JX280148 and A. hydrophilaJQ687063 during $72 \mathrm{~h}$ of incubation (Table 2). The results of co-culture plate counts $\left({\mathrm{x} 10^{10} \mathrm{CFU} \mathrm{ml}}^{-1}\right)$ showed that increasing the count of $C$. bifermentans CPSS2 colonies positively antagonistic against the fish pathogenic bacteria. Interestingly the results showed that $\mathrm{T} 4$ treatment group ( $1 \mathrm{ml}$ pathogenic bacteria with $2 \mathrm{ml}$ C. bifermentansCPSS2) have less $\mathrm{CFU} \mathrm{ml}{ }^{-1}$ count when compare $\mathrm{T} 1$ treatment group $(1 \mathrm{ml}$ pathogenic bacteria with $0.5 \mathrm{ml} C$. bifermentansCPSS2). The growth kinetic plots of co-culture of different treatment group of pathogenic bacteria and C. bifermentans CPSS2 were reflected that with increase in sampling time period OD at $600 \mathrm{~nm}$ was positively higher, the same trends were observed against the all the co-culture samples (Figure 3). Moreover, positive relationship between growth kinetic curves of high peak associated with more colonies of $C$. bifermentansCPSS2 compared to pathogenic fish bacteria in co-culture plate count with increasing time periods signifies the antagonistic activity of $C$. bifermentansCPSS2.

Efficacy of antibacterial activity of Extracellular protein and Intracellular protein under in vitro condition:Intracellular protein (ICP) derived by sonication of $C$. bifermentansCPSS2exhibited the significantly $(\mathrm{p}<0.05)$ high antagonistic effect against $S$. aureus JQ429749 followed by F. columnareATCC 49513and A. hydrophilaJQ687063 and less effective against $E$. tardaJX280148. The higher concentration $(100 \mu 1)$ of ICP of $C$. bifermentans CPSS2 was found more effective compare to less $(50 \mu \mathrm{l})$ of inoculums as the highest zone of inhibition was found $16 \mathrm{~mm}$ in $100 \mu \mathrm{l}$ against $S$. aureus JQ429749 and the lowest value of $7 \mathrm{~mm}$ in $50 \mu 1$ against $E$. tardaJX280148 (Figure 4). However, there was no antagonistic antibacterial activity was observed in extracellular protein and whole cell.

Table 1:- Results of the biochemical tests of $C$. bifermentansCPSS2. 
N.B: "+" and "++ infers "positive" and " highly positive" respectively.

\begin{tabular}{|c|c|}
\hline Name of the Test & Results (+/-) \\
\hline Indole & + \\
\hline Methryl Red(MR) & - \\
\hline Voges-Proskauer (VP) & ++ \\
\hline Citrate utilization & + \\
\hline Oxidase & ++ \\
\hline Catalase & + \\
\hline Mannitol motility & + \\
\hline \multirow{5}{*}{$\begin{array}{l}\text { Triple Sugar Iron(TSI) } \\
\text { a. Yellow butt and red slant } \\
\text { b. Yellow butt and yellow slant } \\
\text { c. Red butt and red slant } \\
\text { d. Cracking of TSI agar }\end{array}$} & \\
\hline & ++ \\
\hline & - \\
\hline & - \\
\hline & + \\
\hline
\end{tabular}

Table 2:-Plate count (x $\left.10^{10} \mathrm{CFU} / \mathrm{ml}\right)$ of different Co-culture ratio of A. E. tarda with C.bifermetans CPSS2 B. A.hydrophilia with C.bifermetans CPSS2 C. S.aureus with C.bifermetans CPSS2 D. F. columnare with C.bifermetans CPSS2

\begin{tabular}{|c|c|c|c|c|c|c|c|c|c|}
\hline \multicolumn{10}{|l|}{$\mathbf{A}$} \\
\hline Time & \multicolumn{2}{|c|}{$0 \mathrm{~h}$} & \multicolumn{2}{|c|}{$24 \mathrm{~h}$} & \multicolumn{2}{|c|}{$48 \mathrm{~h}$} & \multicolumn{2}{|c|}{$72 \mathrm{~h}$} & \\
\hline $\begin{array}{l}\text { Treatment } \\
\mathrm{s}\end{array}$ & E.tarda & $\begin{array}{l}\text { Clostridi } \\
\text { um }\end{array}$ & E.tarda & $\begin{array}{l}\text { Clostridi } \\
\text { um }\end{array}$ & E.tarda & $\begin{array}{l}\text { Clostridi } \\
\text { um }\end{array}$ & E.tarda & $\begin{array}{l}\text { Clostridi } \\
\text { um }\end{array}$ & \\
\hline $\mathrm{T} 1$ & 3.26 & 1.64 & 7.55 & 12.25 & 1.3 & 4.5 & 0.8 & 2.5 & \\
\hline $\mathrm{T} 2$ & 3.23 & 1.7 & 9.1 & 11.3 & 0.5 & 2.55 & 0.2 & 1.2 & \\
\hline T3 & 3.2 & 1.74 & 9 & 10.45 & 0.5 & 0.8 & 0.3 & 0.6 & \\
\hline $\mathrm{T} 4$ & 3.15 & 1.78 & 7.05 & 4.45 & 0.5 & 1 & 0.2 & 1 & \\
\hline \multicolumn{10}{|l|}{ B } \\
\hline $\begin{array}{l}\text { Time } \\
\text { periods }\end{array}$ & \multicolumn{2}{|c|}{$0 \mathrm{~h}$} & \multicolumn{2}{|c|}{$24 \mathrm{~h}$} & \multicolumn{2}{|c|}{$48 \mathrm{~h}$} & \multicolumn{2}{|c|}{$72 \mathrm{~h}$} & \\
\hline $\begin{array}{l}\text { Treatment } \\
\mathrm{s}\end{array}$ & $\begin{array}{l}\text { A. } \\
\text { hydrophila }\end{array}$ & $\begin{array}{l}\text { Clostridi } \\
\text { um }\end{array}$ & $\begin{array}{l}\text { A. } \\
\text { hydrophila }\end{array}$ & $\begin{array}{l}\text { Clostridi } \\
\text { um }\end{array}$ & $\begin{array}{l}\text { A. } \\
\text { hydrophila }\end{array}$ & $\begin{array}{l}\text { Clostridi } \\
\text { um }\end{array}$ & $\begin{array}{l}\text { A. } \\
\text { hydrophila }\end{array}$ & $\begin{array}{l}\text { Clostridi } \\
\text { um }\end{array}$ & \\
\hline $\mathrm{T} 1$ & 3.8 & 1.8 & 14.25 & 18.3 & 1 & 5.35 & 0.8 & 2.05 & \\
\hline $\mathrm{T} 2$ & 3.65 & 1.98 & 9.5 & 20.1 & 1 & 3.7 & 0.75 & 1.59 & \\
\hline $\mathrm{T} 3$ & 3.8 & 2 & 5 & 11.45 & 2.15 & 3.5 & 0.4 & 1.8 & \\
\hline $\mathrm{T} 4$ & 3.6 & 2.2 & 5.9 & 10.35 & 2.3 & 1.05 & 0.1 & 0.8 & \\
\hline \multicolumn{10}{|l|}{$\mathrm{C}$} \\
\hline $\begin{array}{l}\text { Time } \\
\text { periods }\end{array}$ & \multicolumn{2}{|c|}{$0 \mathrm{~h}$} & \multicolumn{2}{|c|}{$24 \mathrm{~h}$} & \multicolumn{2}{|c|}{$48 \mathrm{~h}$} & \multicolumn{2}{|c|}{$72 \mathrm{~h}$} & \\
\hline $\begin{array}{l}\text { Treatment } \\
\mathrm{s}\end{array}$ & $\begin{array}{l}\text { Staphylococ } \\
\text { cus }\end{array}$ & $\begin{array}{l}\text { Clostridi } \\
\text { um }\end{array}$ & $\begin{array}{l}\text { Staphylococ } \\
\text { cus }\end{array}$ & $\begin{array}{l}\text { Clostridi } \\
\text { um }\end{array}$ & $\begin{array}{l}\text { Staphylococ } \\
\text { cus }\end{array}$ & $\begin{array}{l}\text { Clostridi } \\
\text { um }\end{array}$ & $\begin{array}{l}\text { Staphylococ } \\
\text { cus }\end{array}$ & $\begin{array}{l}\text { Clostridi } \\
\text { um }\end{array}$ & \\
\hline $\mathrm{T} 1$ & 2.7 & 1.64 & 1.75 & 8.85 & 0.84 & 9.65 & 0.2 & 5.68 & \\
\hline $\mathrm{T} 2$ & 2.65 & 1.8 & 1.75 & 8.95 & 0.78 & 10.55 & Nil & 6.9 & \\
\hline T3 & 2.72 & 1.88 & 0.3 & 26.5 & 0.1 & 28.5 & Nil & 8.5 & \\
\hline $\mathrm{T} 4$ & 2.65 & 1.9 & 0.2 & 40 & Nil & 45 & Nil & 15.8 & \\
\hline \multicolumn{10}{|l|}{ D } \\
\hline $\begin{array}{l}\text { Time } \\
\text { periods }\end{array}$ & \multicolumn{2}{|c|}{$0 \mathrm{~h}$} & \multicolumn{2}{|c|}{$24 \mathrm{~h}$} & \multicolumn{2}{|c|}{$48 \mathrm{~h}$} & \multicolumn{2}{|c|}{$72 \mathrm{~h}$} & \\
\hline $\begin{array}{l}\text { Treatment } \\
\mathrm{s}\end{array}$ & $\begin{array}{l}\text { Flavobacter } \\
\text { ium }\end{array}$ & $\begin{array}{l}\text { Clostridi } \\
\text { um }\end{array}$ & $\begin{array}{l}\text { Flavobacter } \\
\text { ium }\end{array}$ & $\begin{array}{l}\text { Clostridi } \\
\text { um }\end{array}$ & $\begin{array}{l}\text { Flavobacter } \\
\text { ium }\end{array}$ & $\begin{array}{l}\text { Clostridi } \\
\text { um }\end{array}$ & $\begin{array}{l}\text { Flavobacter } \\
\text { ium }\end{array}$ & $\begin{array}{l}\text { Clostridi } \\
\text { um }\end{array}$ & \\
\hline $\mathrm{T} 1$ & 3.6 & 1.8 & 7.55 & 12.25 & 2.4 & 1.4 & 0.4 & 6.84 & \\
\hline $\mathrm{T} 2$ & 3.4 & 2 & 9.1 & 10.8 & 1.5 & 6.4 & 0.8 & 10.55 & \\
\hline T3 & 3.8 & 1.9 & 9.5 & 10.45 & 1.85 & 25.45 & Nil & 8.54 & \\
\hline $\mathrm{T} 4$ & 3.2 & 2 & 8.1 & 14.2 & 3.2 & 20.85 & Nil & 10.25 & \\
\hline
\end{tabular}



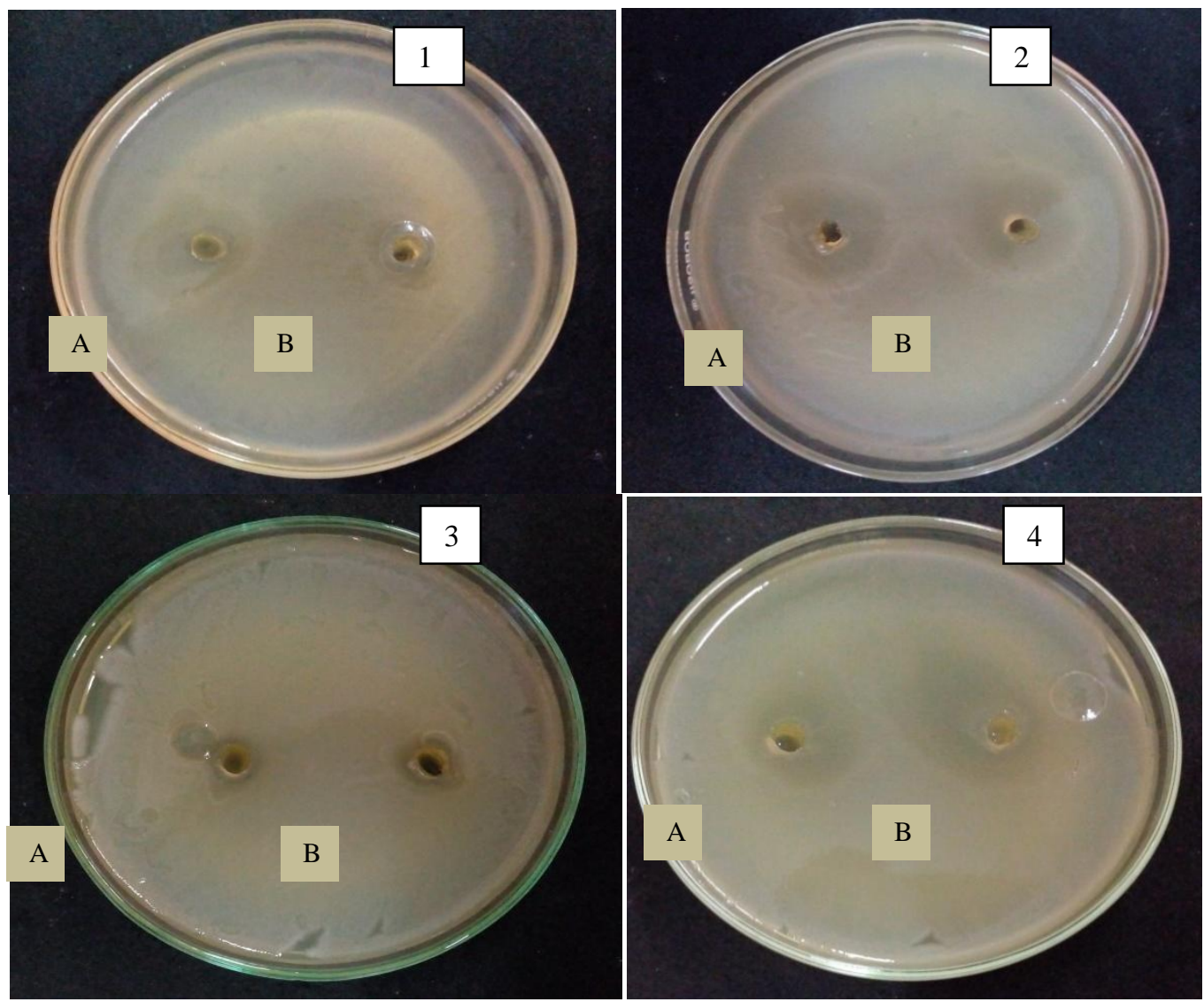

A: $100 \mu \mathrm{l}$ and B: $50 \mu \mathrm{l}$ of inoculum

Figure 1:- Zone of inhibition (in mm) formed antagonistic activity of live Clostridium bifermentansCPSS2against 1. Flavobacteriumcolumnare ATCC 49513 2.Staphylococcus aureus JQ429749 3.Edwardsiellatarda JX280148 and 4.AeromonashydrophilaJQ687063

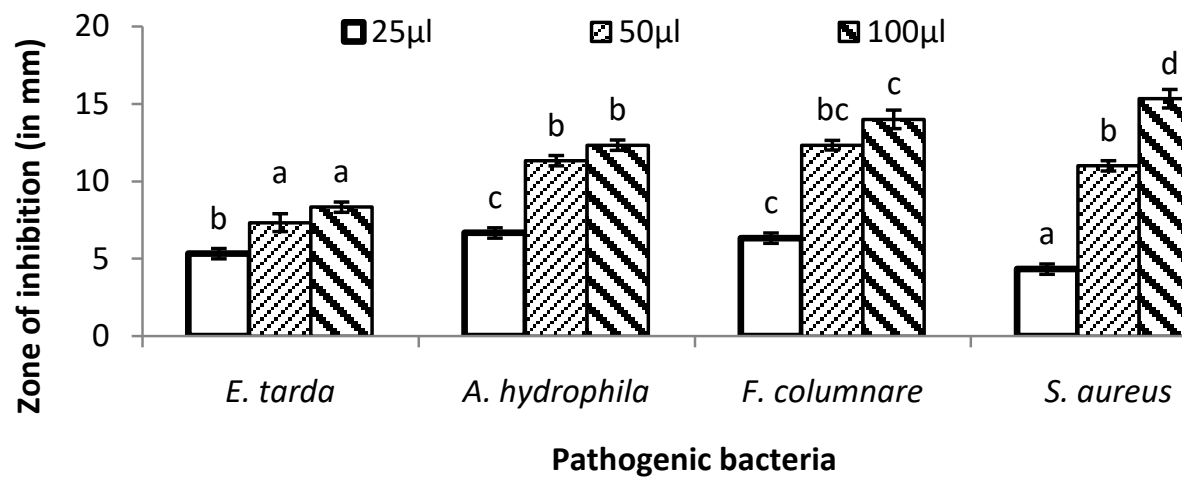

Figure 2:- Antagonistic effect measured in zone of inhibition (in $\mathrm{mm}$ ) of varied amount of live Clostridium bifermentans CPSS2 against some selected fish pathogenic bacteria. The data is represented with different superscript differ significantly $(\mathrm{p}<0.05)$ and express as mean \pm SE. 

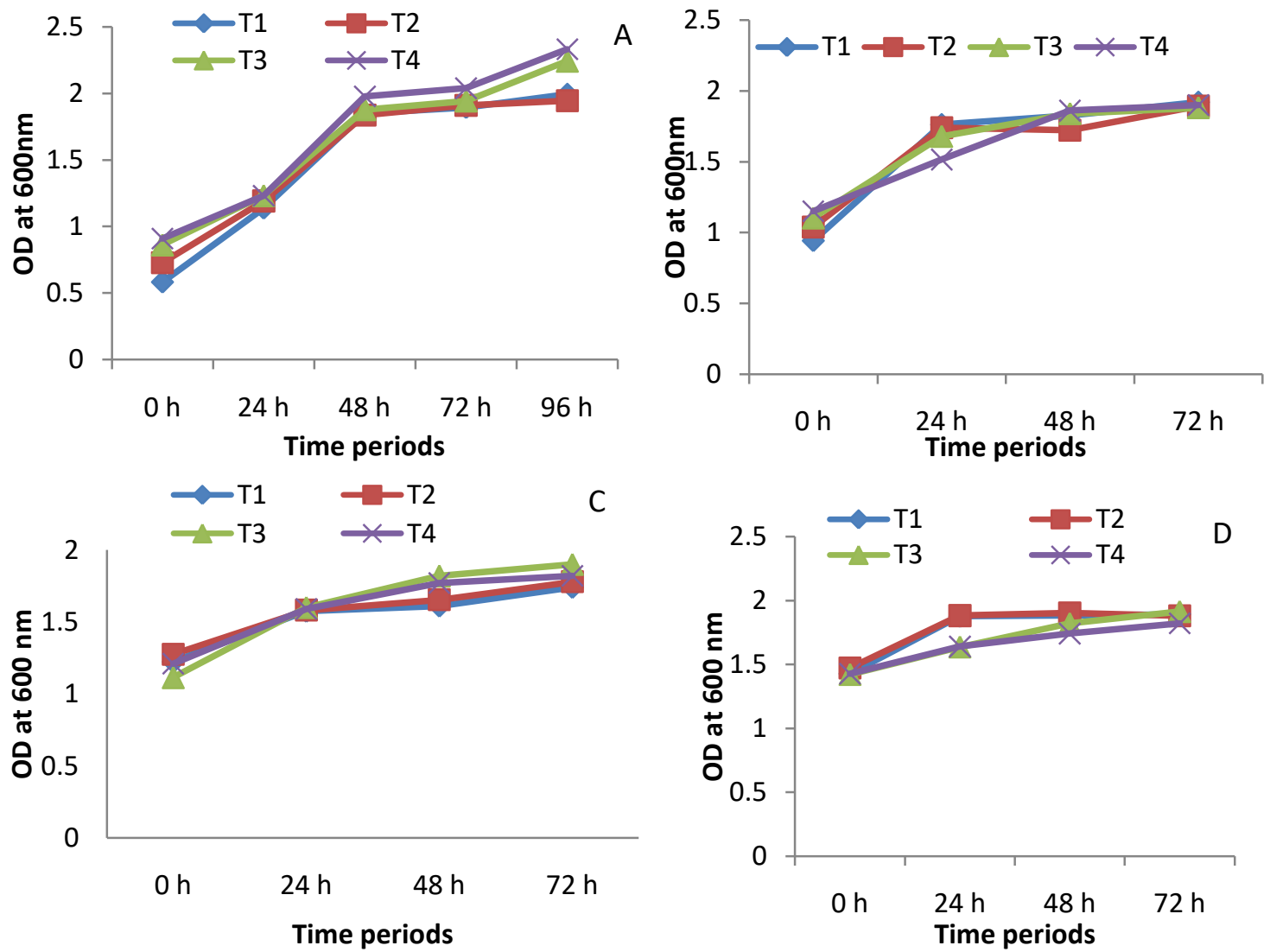

Figure 3:- OD at $600 \mathrm{~nm}$ of co-culture of varied ratio of A. Flavobacteriumcolumnare and Clostridium bifermentans CPSS2 B. Staphylococcus aureus and Clostridium bifermentansCPSS2 C. Aeromonashydrophila and Clostridium bifermentans CPSS2 D. Edwardisellatarda and Clostridium bifermentans CPSS2 at different time periods.

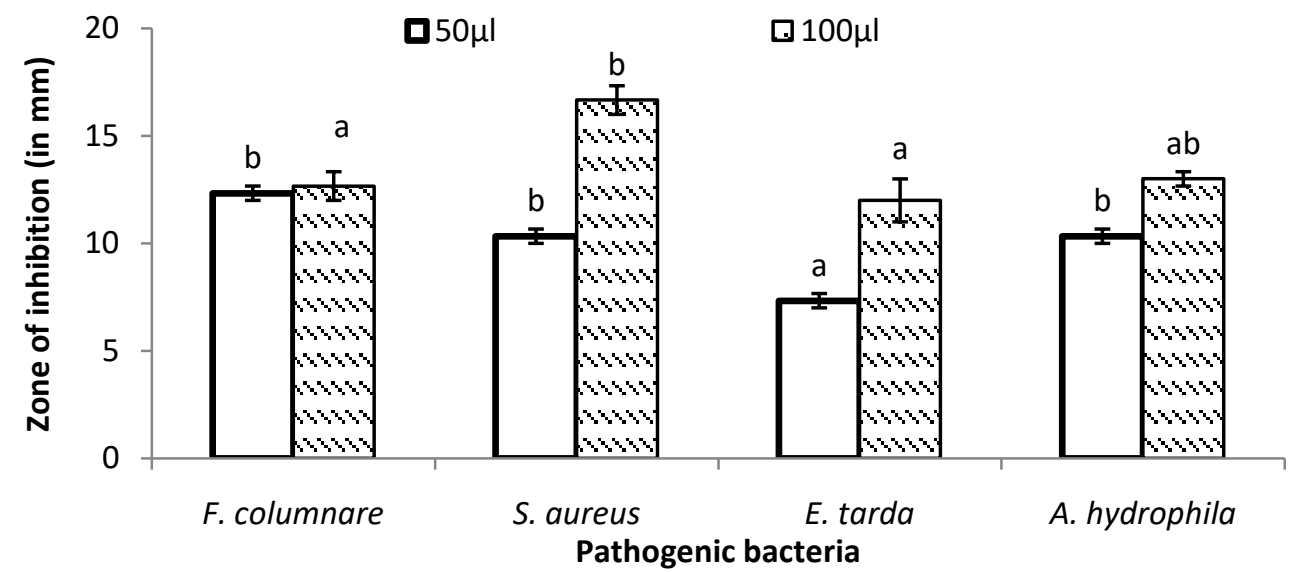

Figure 4:- Zone of Inhibition (in $\mathrm{mm}$ ) formed by varied amount of intracellular protein of Clostridium bifermentans CPSS2 against some selected fish pathogenic bacteria. The data is represented with different superscript differ significantly $(\mathrm{p}<0.05)$ and express as mean \pm SE. 

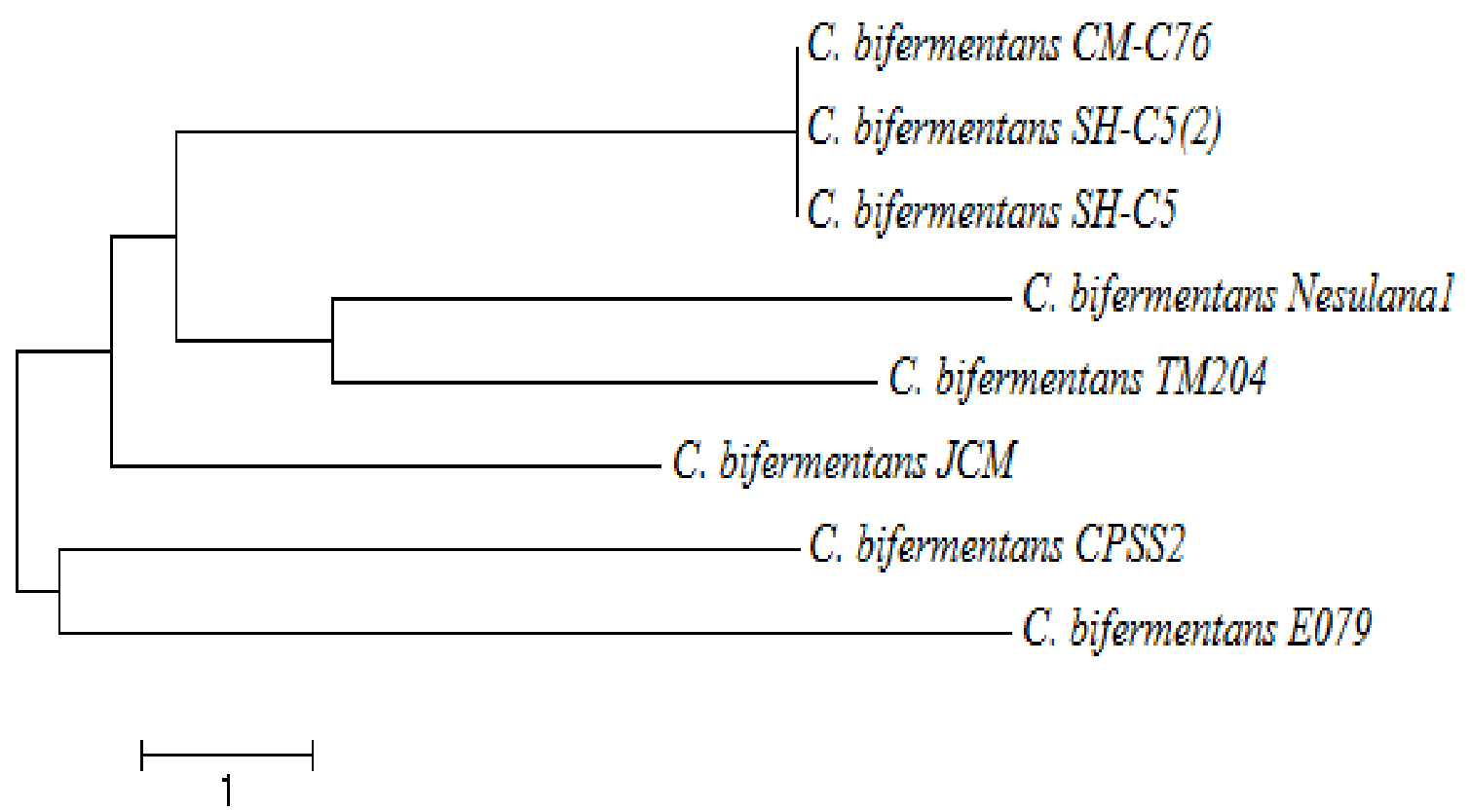

Figure 5:- Neighbor-joining tree showing the phylogenetic relationships between the isolates and the type strains based on 16S rRNA gene sequences, only some representative isolates were indicated.

\section{Discussions:-}

Presently chemotherapeutic agents are being used to control the majority of bacterial diseases. However, several limitations in their application and negative have impact on environment; attract to search an alternative to biocontrol agents. This possibility has already been highlighted by several workers (Austin,Stuckey, Robertson, Effendi \& D 1995; Robertson, O'Dowd, Burrells, Williams \& Austin 2000; Ringo, Lodemel, Myklebust, Kaino, Mayhew \& Olsen 2001). In the present study, biocontrol agent was investigated under in vitro condition as potential competitor against selected fish pathogenic bacteria.

Among six bacterial isolates, one isolate of $C$. bifermentans CPSS2 has been evaluated for biocontrol agent. Indeed, not more than $1 \%$ of the environmental bacterial communities are cultivable (Amann, Binder, Olson, Chisholm, Devereux \& Stahl 1990). Moreover, in the present study, the predominant bacterial group isolated from soil of aquaculture ponds was composed of Gram positive bacteria Clostridium and Bacillus spp. Similarly, 12 strains belong to genus Clostridium were isolated and identified from soil and composts by sequencing as C. bifermentans and C. butyricum (Leja, Myszka, Olejnik-Schmidt, Juzwa\&Czaczyk 2014). Further, they reported the morphology and biochemical characteristics of $C$. bifermentans strains in TSA medium having opaque, black, circular, low convex colonies with slightly undulated margins. The result of our findings confirms the characteristics of $C$. bifermentans strains (Prevot\&Malgras 1950; Regan \& Crawford 1994).

Further, the results of biochemical characterization showed that isolate is negative for urease, inuline, trehalose and rhamnose fermentation and positive for indole, mannitol assimilation, citrate utilisation, glucose and mannose fermentation. C. bifermentans strains was reported as indole positive (Regan and Crawford 1994; Nachman, Kaul, Li, Slim, Filippo \& Horn 1989). Similar results were documented for Clostridium which showed indole positive and urease negative (Brooks, Moss \& Dowell 1969). The ability of C. bifermentans to saccharide fermentation along with fermented glucose, fructose, maltose, glycerol, and sorbitol were reported by (Brooks \& Epps 1958).

Results from agar gel diffusion assays clearly indicate that $C$. bifermentans CPSS2 have antagonistic effects against selected fish bacterial pathogens. It shows that the mechanism involved in antagonistic effect is a competitive exclusion or a synthesis of non-diffusible antimicrobial which is validated by co-culture inhibition assay. Further, in vitro antibacterial efficacy of intracellular protein (IP) strengthens the finding that Clostridium has specific antagonistic antibacterial activity. In this respect, zone of inhibition was observed on agar plates and growth kinetic plot was drawn which confer the antibacterial activity in co-culture. Clostridium butyricum has been evaluated as a 
probiotic candidate and showed antimicrobial activity against A. hydrophila and Vibrio anguillarum under in vitro condition (Pan, Wu, Zhang, Song, Tang \& Zhao 2008). Similarly, antagonistic activity of cellular components of Pseudomonas species was identified as biocontrol agent against $A$. hydrophila and its effect on Cirrhinusmrigala(Das, Samal, Samantaray, Sethi, Pattanaik\& Mishra 2006). Further heat stable B. subtilis isolate derived from mangrove forest was exhibited antagonistic activity against fish pathogenic bacteria (Das, Neha, Roy, Muduli, Swain, Mishra\&Jayasankar 2014).

The concept of inhibition of pathogens by the growth of environmental or resident bacteria was first suggested in birds (Nurmi\&Rantala 1973). The competitive exclusion exerted by biocontrol against pathogens was also reported in fish, crustaceans, and other aquatic organisms (Balcazar, DeBlas, Ruiz-Zarzuela, Vendrell\&Muzquiz 2004). Competitive exclusion is the most promising mode of probiotic action because it involves many different processes and factors which are very important in microbial dynamics (Smith 1993). The mechanism related of nutrient competition, extracellular protein like bacteriocin production, intracellular protein or alteration in medium chemical properties are widely responsible for inhibit the another group of bacteria. In order to become more competitive, pathogens need to evolve and to gain new functions. Each of these new functions facing a single process implied in the competition. On the contrary, when competitors inhibit growth by secretion of a single antimicrobial agent, the pathogen needs to acquire only one specific resistance gene to this specific antimicrobial agent (Moriarty 1998).

The antibacterial activity of $C$. bifermentans CPSS2 was observed against selected fish pathogenic bacteria but at different level in agar gel diffusion and co-culture inhibition assay. The result suggests that Gram positive and Gram negative bacterial morphological differences may play a critical role in their protection. In the present study, the whole live $C$. bifermentansCPSS2 and intracellular protein have showed more antibacterial activity against Gram positive $S$. aureus JQ429749 compared to Gram negative E. tarda JX280148 and A. hydrophila JQ687063. Similar mechanism was reported for selection of probiotic bacteria and highlighted the importance of a non-diffusible antimicrobial compound (Oliveira, Oliveira \& Gloria 2008). The target of bacteriocin is the cytoplasmic membrane, but Gram-negative bacteria like Flavobacterium do have a protective barrier provided by the lipopolysaccharide of the outer membrane. However, some circumstances can disrupt the integrity of this barrier and increase the effectiveness of bacteriocin against gram-negative bacteria (Stevens, Sheldon, Klapes\&Klaenhammer 1991; Mortvedt-Abildgaard, Nissen-Meyer, Jelle, Grenov, Skaugen\&Nes 1995). In the conclusive remarks, the study was conducted to isolate and characterize the biocontrol bacteria C. bifermantan CPSS2 which showed in-vitro antagonistic activity against number of fish pathogenic bacteria viz., Flavobacteriumcolumnare ATCC 49513, Staphylococcus aureus JQ429749, Aeromonashydrophila JQ687063 and Edwardisellatarda JX280148. Agar diffusion assay combined with broth co-culture assays and the screening of inhibitory compounds from bacteria, have clearly demonstrated that live bacteria and intracellular protein isolated from $C$. bifermentans CPSS2 could be a possible means of biocontrol agent which could compete with fish pathogenic bacteria. Thus, the present study opens a new idea to evaluate antibacterial efficacy of $C$. bifermentans CPSS2 under in vivo condition and its role as biocontrol agent. So, it would be a promising bio-control agent in near future in the freshwater aquaculture sector as well as the strain isolated in this study would be a valuable resource deserving future detailed studies.

\section{Acknowledgement:-}

All the authors are thankful to Director, ICAR-CIFA, Kausalyaganga, Bhubaneswar for providing all kinds of facility to carry out the present research work.

\section{References:-}

1. Amann, R.I., Binder, B.J., Olson, R.J., Chisholm, S.W., Devereux, R. and Stahl, D.A. (1990): Combination of 16S rRNA-targeted oligonucleotide probes with flow cytometry for analyzing mixed microbial populations. Appl. Environ. Microbiol.,56: 1919-1925.

2. Austin, B. and Rodgers, C.J. (1981): Preliminary observations on Aeromonassalmonicida vaccines. Developmental Biol. Stand,49: 387-393.

3. Austin, B., Stuckey, L.F., Robertson, P.A.W., Effendi, I. and Griffith, D.R.W. (1995): A probiotic strain of Vibrio alginolyticus effective in reducing diseases caused by Aeromonassalmonicida, Vibrio anguillarumand Vibrio ordalii. J. Fish. Dis., 18: 93-96.

4. Authira, R.R., Kirithika, M., Venkatesan, S., Ganesan, R., and Muthuchelian, K. (2011) : Studies on in vivo and in vitro antagonistic activity of probiotics against fish pathogens. J. Biol. Res.,4: 271-275. 
5. Balcazar, J., DeBlas, I., Ruiz-Zarzuela, I., Vendrell, D., and Muzquiz, J. (2004) : Probiotics: a tool for the future of fish and shellfish health management. J. Aquacult. Tropics, 19: 239-242.

6. Benson, H.J. (1994) Microbiological applications. Dubuque, USA: Wm. C. Brown Publishers.

7. Bondad-Reantaso, M.. G., Rohana, P. Subasinghe, J. Richard. A., Ogawa, K., Chinabut, S., Adlard, R., Tan, Z. and Shariff, M. (2005) Disease and Health management in Asian aquaculture. Vet. Parasitol.,132: 249-272.

8. Brooks, E. (1958): Taxonomic Studies of the Genus Clostridium: Clostridium bifermentans and C. sordellii. J.Gen.Microbiol.,88: 144-155.

9. Brooks, J.B., Moss, C.W. and Dowell, V.R. (1969): Differentiation between Clostridium sordellii and Clostridium bifermentans by gas chromatography. J. Bacteriol. 20: 528-530.

10. Collins, C.H., Lyne, P.M., Grange J.M. (1995) :Colllins\&Lyne's microbiological methods. Oxford: Butterworth-Heinemann Ltd.

11. Das, B.K., Neha, Nidhi R.G., Roy, P., Muduli, A.K., Swain, P., Mishra, S.S. and Jayasankar, P. (2014): Antagonistic activity of cellular components of Bacillus subtilis AN11 against bacterial pathogens. Int. J. Current Microbiol. Applied Sci., 3: 795-809.

12. Das, B.K., Samal, S.K., Samantaray, B.R., Sethi, S., Pattanaik, P. and Mishra, B.K. (2006) : Antagonistic activity of cellular components of Pseudomonas species against Aeromonashydrophila. Aquaculture,253: 1724.

13. Desriac, F., Defer, D., Bourgougnon, N., Brillet, B., Le Chevalier, P. and Fleury, Y. (2010) : Bacteriocin as weapons in the marine animal-associated bacteria warfare: inventory and potential applications as an aquaculture probiotic. Marine Drugs, 8: 1153-1177.

14. Dhanasekaran, D., Subhasish, Saha.,Thajuddin, N. and Panneerselvam, A. (2008) : Probiotic effect of Lactobacillus isolates against bacterial pathogens in Clariasorientalis. FactaUniversitatis Series: Medicine and Biology.

15. Ding, C. and He, J. (2010) : Effect of antibiotics in the environment on microbial populations. Appl. Microbiol. \&Biotechnol., 87: 925-941.

16. Gram, L. and Melchiosen, J. (1996) : Interaction between fish spoilage bacteria Pseudomonas sp. \&Shewanellaputrefacians in fish extracts \& fish tissue. J. Appl. Bacteriol., 80: 589-595.

17. Harris, M.A., Daeschel, M.E.S.. and Klaenhammer, T .R.. (1989): Antimicrobial activity of lactic acid bacteria against Listeria monocytogenes. J. Food Protection, 52: 384-387.

18. Joseph, V., Sasidharan, A., Raghul, S., Nair P. H..and Bhat G.S.. (2013):Occurrence of potential pathogenic Aeromonas species in tropical seafood, aquafarms and mangroves off Cochin coast in South India. Vet. World, doi:10.5455/300-306.

19. Lara-Flores, M. (2011) : The use of probiotic in aquaculture an overview. Int. Res. J. Microbiol., 2: 471-478.

20. Leja, K., Myszka, K., Olejnik-Schmidt, A. K., Juzwa, W. and Czaczyk, K. (2014) : Selection and characterization of Clostridium bifermentans strains from natural environment capable of producing 1, 3propanediol under microaerophilic conditions. African J. Microbiol. Res., 8: 1187-1197.

21. Merrifield Daniel, L., Dimitroglou, A. ,Foey, A.S., Davies, J., Remi, T.M., Baker, Jarl. B.,,Castex, M. and Ring $\varnothing$, E.. (2010) : The current status and future focus of probiotic and prebiotic applications for salmonids. Aquaculture, 302:1-18.

22. Moriarty, D.J.W. (1998) : Control of luminous Vibrio species in penaeid aquaculture ponds. Aquaculture, 164: 351-358.

23. Mortvedt-Abildgaard, C., Nissen-Meyer, J., Jelle, B., Grenov, B. Skaugen, M. and Nes, I. (1995) : Production and $\mathrm{pH}$-dependent bactericidal activity of lactocin S, a lantibiotic from Lactobacillussake L45. J. Appl. Environ. Microbiol.,61: 175-179.

24. MPEDA. (2014) http://www.mpeda.com/brofd.pdf.

25. Murray, M.G. and Thompson, W.F. (1980) : Rapid Isolation of High Molecular Weight Plant DNA. Nucleic Acids Res., 19, 4321-4326

26. Nachman, S., Kaul, A., Li, KI., Slim, M.S., Filippo, J.A. and Horn, K.V. (1989) : Liver abscess caused by Clostridium bifermentans following blunt abdominal trauma. J. Clin. Microbiol., 27:1137-1138.

27. Nurmi, E. and Rantala, M. (1973) : New aspects of salmonella infection in broiler production. Nature, 241: $210-211$.

28. Oliveira, R.B.P., Oliveira, D.L.A. and Gloria, B.M.A. (2008) : Screening of lactic acid bacteria from vacuum packaged beef for antimicrobial activity. Brazilian J. Microbiol., 39: 368-374.

29. Pan, X., Wu T., Zhang, L., Song, Z., Tang, H. and Zhao, Z. (2008) : In vitro evaluation on adherence and antimicrobial properties of a candidate probiotic Clostridium butyricum CB2 for farmed fish. J. Appl. Microbiol.,105: 1623-1629. 
30. Prevot, A.R. and Malgras, J. (1950) :Recherches sur l'hémolysine de Cl sordellii. Annales de l'Institut Pasteur. 78: 133.

31. Regan, K.M. and Crawford, R.L. (1994) :Characterization of Clostridium bifermentans and its biotransformation of 2,4,6-trinitrotoluene (tnt) and 1,3,5-triaza-1,3,5-trinitrocyclohexane (rdx). Biotechnol. Lett.,24:1081-1086.

32. Resende, J.A., Silva, V.L., Fontes, C.O., Souza-Filho, J.A., Rocha de Oliveira, T. L., Coelho, C. M. and Diniz, C.G. (2011) : Multidrug-resistance and toxic metal tolerance of medically important bacteria isolated from an aquaculture system. Microbes and Environments JSME, 27: 449-455.

33. Ringo, E., Lodemel, J.B., Myklebust, R., Kaino, T., Mayhew, T.M. and Olsen, R.E. (2001) : Epithelium associated bacteria in the gastrointestinal tract of Arctic charr (SalvelinusalpinusL.) An electron microscopical study. J. Appl. Microbiol., 90: 294-300.

34. Robertson, P.A.W., O'Dowd, C., Burrells, C., Williams, P. and Austin, B. (2000) : Use of Carnobacterium sp. as a probiotic for Atlantic salmon (Salmo salar L.) and rainbow trout (Oncorhynchus mykiss, Walbaum). Aquaculture, 185: 235-243.

35. Seenivasan, C., SaravanaBhavan, P., Radhakrishnan, S. and Muralisankar, T. (2012) : Effects of probiotics on survival, growth and biochemical constituents of freshwater prawn Macrobrachiumrosenbergiipost larvae, Turk. J. Fish. Aquat. Sc., 12: 331-338.

36. Smith, V.H. (1993) : Applicability of resource-ratio theory to microbial ecology. Limnol. Oceanogr.,38: 239249.

37. Spanggaard, B., Huber, I., Nielsen, J., Sick, E.B., Pipper, C.B., Martinussen, T., Slierendrecht, W.J. and Gram, L.J. (2001) : The probiotic potential against vibriosis of the indigenous microflora of rainbow trout. Environ. Microbiol., 3: 755-765.

38. Stevens, K.A., Sheldon, B.W., Klapes, N.A. and Klaenhammer, T.R. (1991) : Nisin treatment for inactivation of Salmonella species and other gram negative bacteria. Appl. Environ. Microbiol.,57: 3613-3615.

39. Subasinghe, R., Soto, D. and Jia, J. (2009) : Global aquaculture and its role in sustainable development. Rev. Aquacult.,1: 2-9.

40. Tabak, S., Maghnia, D. and Bensoltane, A. (2012) : The antagonistic activity of the lactic acid bacteria (Streptococcus thermophilus, Bifidobacterium bifidumandLactobacillus bulgaricus) against Helicobacter pylori responsible for the gastroduodenals diseases. J. Agricult. Sci. . Technol.,2: 709-715.

41. Tamura, K., Peterson, D., Peterson, N., Stecher, G., Nei, M. and Kumar, S. (2011) MEGA5: Molecular Evolutionary Genetics Analysis Using Maximum Likelihood, Evolutionary Distance, and Maximum Parsimony Methods. Mol. Biol. Evol., 28: 2731-2739.

42. Verschuere, L., Rambaut, G., Sorgeloos, P. and Vestracte, W. (2000) : Probiotic bacteria as biocontrol agent in aquaculture. Microbiol. Mol. Biol. Rev.,64: 655-671.

43. Vidya, R. and Lyer, P.R. (2010) : Antagonistic activity of probiotic organism against vibrio cholera and Cryptococcudneoformans. Malaysian J. Microbiol., 6: 41-46.

44. Vine, N.G., Leukes, W.D. and Kaiser, H. (2004) : In vitro growth characteristics of five candidate aquaculture probiotics and two fish pathogens grown in fish intestinal mucus. FEMS Microbiol. Lett., 231: 145-152. 